\title{
Taşkın Farkındalık ve Erken Uyarı Sistemleri Değerlendirmesi: Trabzon Beşikdüzü Örneği
}

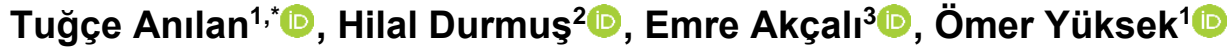 \\ ${ }^{1}$ Karadeniz Teknik Üniversitesi, Mühendislik Fakültesi, Inşaat Mühendisliği Bölümü, 61080, Trabzon. \\ ${ }^{2}$ Trabzon Hilal Yapı Denetim Limited Şirketi, 61040, Trabzon. \\ ${ }^{3}$ Devlet Su Işleri, 22. Bölge Müdürlüğü, 61220, Trabzon.
}

\section{Özet}

Bu çalışmada 21 Eylül 2016 tarihinde Trabzon'un Beşikdüzü İlçesinde meydana gelen ve büyük miktarda can ve mal kaybıyla sonuçlanan taşkın, hidrolojik ve sosyal yönden incelenmiştir. Bu amaçla, ilk olarak yaşanan taşkının kaç yıl tekerrür süreli taşkın debisine karşılık geldiğini belirlemek için bölgesel taşkın frekans analizi ile T=2, 5, 10, 25, 50, 100, 500 ve 1000 yll tekerrür süreli taşkın debileri hesaplanmıştır. İkinci olarak; taşkın riski farkındalığı ve erken uyarı sistemindeki ihtiyaçları belirlemek adına taşkın olayını yaşayan bölge halkıyla anket yapılmıştır. Genel farkındalık kapsamında halkın; taşkın öncesinde, taşkın sırasında veya sonrasında sunulan önlemlerden, stratejilerden ve uygulanan politikalardan ne kadar haberdar olduğu ölçülmüştür. Erken uyarı farkındalığı kapsamında ise, halkın erken uyarı sistemlerinden beklentileri ve bu konudaki bilinç düzeyleri incelenmiștir. Kișinin erken uyarı alması ya da almaması durumunda harekete geçme eğilimi ise bir olay ağacı üzerinde değerlendirilmiş olup, harekete geçmenin bağlı olduğu faktörler incelenmiştir. Çalışmanın sonunda, erken uyarı sistemleri ilgili öneriler sunulmuştur.

\section{Assessment of Flood Awareness and Early Warning Systems: The Case of Beşikdüzü, Trabzon}

\begin{abstract}
In this study, the flood, occurred in Beşikdüzü District, Trabzon, on 21 September 2016 and resulted in the large amount of life loss and property, was investigated in terms of hydrological and social aspects. For this purpose, firstly, various flood discharges for different return periods were estimated by regional flood frequency analysis in order to determine the flood quantile of the Beşikdüzü flood. Secondly, for determining flood risk awareness and needs in the early warning system, a survey was conducted with the people living in the region. Within the scope of general awareness, the people's knowledge of the measures, strategies and policies implemented before, during or after the flood, was investigated. Within the scope of early warning awareness, the expectations of the people from early warning systems and their awareness on this issue were examined. The tendency to take action upon receiving early warnings or not, was evaluated on an event tree, and the factors depending on taking action were examined. At the end of the study, recommendations about early warning systems were also presented.
\end{abstract}

$\underline{\text { Keywords }}$

Regional Flood Frequency Analysis, L-Moments, Flood Awareness, Flood Early Warning Systems

\section{Giriş}

Taşkınlar tüm dünyada olduğu gibi Türkiye'de de her yıl büyük ekonomik zarara ve can kayıplarına sebep olan doğal felaketlerdendir. Türkiye'de depremlerden sonra en büyük can kaybı ve ekonomik zarar taşkın olaylarında yaşanmaktadır (Anılan vd. 2018). Belirli bir yağış olayının taşkın oluşturma riski, drenaj havzasının büyüklüğü, havzanın topoğrafyası, havza içindeki kentsel kullanım miktarı, vb. gibi faktörlerden büyük ölçüde etkilenir (Doswell vd. 1996). Ancak taşkın afetlerinin yalnızca meteorolojik oluşumlara bağlı olarak ifade edilmesi mümkün değildir. Ekonomik gelişme faaliyetlerinin yoğun bir biçimde devam ettiği ülkelerde, sanayileşme ve sektör çeşitliliğinin beraberinde getirdiği kentleşme aktivitesi, akarsu havzalarının muhtelif kesimlerindeki insan faaliyetinin çeşitliliğini ve yoğunluğunu da büyük ölçüde arttırmaktadır. Bu durum ise havza bütünündeki hidrolojik dengeyi bozmakta ve sonuçta büyük miktarda can ve mal kaybına yol açan taşkın afetleri gözlenmektedir.

\footnotetext{
* Sorumlu Yazar: Tel: +90 (462) 3772654 Faks: +90 (462) 3772606

E-posta: tugcekoc@ktu.edu.tr (Anılan T), hilaldurmus92@gmail.com (Durmuş H),

Gönderim Tarihi / Received : 18/04/2020 Kabul Tarihi / Accepted 
Akarsu havzaları içinde büyüyen yerleşimler, açılan yeni yollar ve kurulan yeni tesisler ile arazi yapısı değişmekte, elverişsiz tarım yöntemleri ile topraklar daha yoğun bir şekilde kullanılmakta, ormanlar ve meralar tahrip edilmekte, tüm bu koşullarda taşkın afetleri giderek daha büyük ve sık olarak görülmektedir (Uşkay ve Aksu 2002).

Taşkın sırasında yaşanan can ve mal kayıplarını en aza indirgemek için akarsu düzenlemesi, sel kapanları, sediment tutucu tersip bentleri, derivasyonlu geciktirme havuzları gibi yapısal taşkın kontrol tesislerinin yanı sıra; taşkın yönetim planı hazırlamak, taşkın tehlike haritası hazırlamak, taşkın yatağı içinde yapılaşmayı önlemek/sınırlamak, taşkın erken uyarı sistemleri geliştirmek, taşkın farkındalığı konusunda halkı bilgilendirmek, doğaya müdahaleleri engellemek, taşkın esnasındaki tahliye faaliyetlerini planlamak gibi yapısal olmayan taşkın kontrol yöntemleri de mevcuttur (Akçalı 2018).

Taşkın riskine, bu riskle nasıl başa çıkılacağına ve taşkın öncesinde, esnasında ve sonrasında yapılması gerekenlere yönelik farkındalığın arttırılması, taşkına karşı direncin arttııılmasının en önemli bileşenlerindendir. Bunun yanı sıra, farkındalığın arttırılması, riskleri arttıran ve azaltan faaliyetlere ilişkin halkın bilinçlendirilmesini de içermektedir ki bu da taşkına yönelik önlemlerin başarılı olmasında çok önemli bir faktördür (SYGM 2017). Taşkın erken uyarılarına zamanında ve etkili tepki verme eğilimi ülkelerin gelişmişlik düzeyine bağlı olduğu kadar, afete maruz kalan insanların yaş, cinsiyet, eğitim düzeyi gibi özelliklerine de bağlıdır. Resmi ya da resmi olmayan herhangi bir uyarıya maruz kalan kişilerin bu durum karşısında nasıl davranması gerektiğini bilmemesi, uyarıya tam güvenmeyip çevreden onay beklemesi ve uyarının kendisi için geçerli olmadığını düşünmesi gibi nedenlerden dolayı zamanında harekete geçilemeyebilir. Bu da taşkın zararlarının çok daha ciddi boyutlara ulaşmasına sebep olur. Bundan dolayı, taşkın zararlarını önleme planlamalarında mühendislik konularını sosyolojik etkileri ile çalışmak oldukça önemlidir.

Parker vd. (2009), taşkın erken uyarı farkındalık belirlenmesine yönelik yaptıkları anket çalışmasında, bireylerin taşkın uyarılarına yanıt verememesinin ya da yanlış tepkiler vermesinin altında yatan psikolojik, sosyal ve ekonomik faktörleri incelemişlerdir. Çalışmaları neticesinde, kamunun taşkın iletişiminin iyileştirilmesi ve halk eğitim kampanyaları ile insanların zihinlerindeki sorulara basit cevaplar sunarak ek bilgi sağlaması gerektiğini belirtmişlerdir. Ayrıca, kişilerin birbirlerini uyarmaları yerine bireylerin taşkın uyarılarıyla beraber karar alma sürecinde erken uyarı sistemine karşı güvene ihtiyacı olduğunu ve bu güvenin kişinin karar vererek harekete geçme sürecine olumlu yansıyacağını savunmuşlardır. Taşkın erken uyarıda harekete geçme eylemini adına yaptıkları çalışmada Molinari ve Handmer (2011), bu harekete geçme eğiliminin uyarıyı fark etmek, uyarıya güvenmek ya da onay aramak gibi parametrelere bağlı olduğunu ve bu parametrelerin her birinin değişmesiyle beraber uyarıya cevap verebilme yeteneğindeki değişimi gözlemlemişlerdir. Her bir değişkenin nihai taşkın kaybı rakamını etkilemesinin yanı sıra, potansiyel iyileştirmelerin de uyarı sistemine olan katkısını analiz etmişlerdir. Alfieri vd. (2012), çalışmalarında, erken uyarı sistemlerine yönelik farkındalığı arttırmak ve aynı zamanda afet sonrası müdahale ve iyileşmeye dayanmak yerine, risk önleme kültürünün geliştirilmesine katkıda bulunmayı amaçlamıştır. Bunun için, erken uyarı sisteminin politikalara ve risk yönetimi planlarına dahil edilmesi, kolay erişilebilir ve anlaşılır eğitimlerle bu sistemlerin tüm devlet kademelerine uygun şekilde entegre edilmesi gerektiğini gözlemlemişlerdir. Kamu kuruluşlarının katılımı ve tehlike tespit yöntemleri ve performansları hakkında ek bilgilerin insanların uyarı sistemlerine güvenmelerini ve dolayısıyla bunlardan faydalanmalarını sağladığını vurgulamışlardır. Gautam ve Phaiju (2013), toplum temelli erken uyarı sisteminin uyarıya verilen cevaplar üzerindeki etkisini araştırırken taşkın izleme ve tahmin istasyonlarından alınan verilerin bölge afet yardım komitesi, yerel afet yönetimi, yerel sivil toplum kuruluşları ve yerel medyayı içeren bir ağ kurularak, uyarıların halka iletilmesinde başarıya ulaşıldığını gözlemlemişlerdir. Bununla birlikte devlet kurumlarının, erken uyarı sistemlerini afet riskini azaltma ve geliştirme planları ve programlarına dahil etmeye başlamasıyla, toplumun donanımlı hale getirilmesi ve altyapıların geliştirilmesinin taşkın riskini azaltmada etkili olduğu gözlemlenmiştir. Karaman (2018), afet yönetimi sürecinde başarının sağlanması için idarenin sadece bilgi alan değil; aynı zamanda bilgi veren konumunda olması ve halka güven vermesi gerektiğini belirtmiş, kurumsal bütünleşikliğin, afet yönetimi sürecinde güvene ve iş birliğine dayalı başarının sağlanmasında dikkat edilmesi gereken önemli bir yönetsel tercih olduğunu ortaya koymuştur. Kamu yönetimi teşkilatlanmasında her seviyede idarenin, topluma kapasitesinin yeterliliği hakkında güven vermesi gerektiği sonucuna varmıştır. Literatürdeki çalışmalar değerlendirildiğinde, toplum temelli taşkın erken uyarı sistemlerinin geliştirilmesi ve var olan sistemlerin iyileştirilmesi önerilmiştir. Halkın uyarılara yanıt verebilmesinde etkili olan faktörler incelenerek, uyarıların zamanında ve güvenilir olmasıyla beraber daha etkili sonuç alınabileceği gözlemlenmiştir.

Bu çalışmada; 21 Eylül 2016 tarihinde büyük bir taşkın felaketinde can ve mal kaybı yaşayan Trabzon İli Beşikdüzü halkının herhangi bir erken uyarı karşısında veya uyarı almadan harekete geçebilme eğilimleri ve sonuçları incelenmiştir. Bu bağlamda, öncelikle yaşanan taşkının kaç yıl tekerrür süreli taşkın debisine karşılık geldiğini belirlemek için bölgesel taşkın frekans analizi ile çeşitli tekerrür süreli taşkın debileri hesaplanmıştır. Hesaplanan debiler yaşanan söz konusu afet anındaki taşkın debisi ile karşılaştırılmış ve ilçenin taşkınlardan zarar görebilirlik riski farklı tekerrür süreli debiler için irdelenmiştir. Daha sonra taşkın riski farkındalık, halkın harekete geçme eğilimleri ve erken uyarı sistemindeki eksiklikleri belirlemek adına bölge halkıyla 'Taşkın Farkındalık ve Taşkın Erken Uyarı Anında İnsan Davranışları' üzerine anket yapılmıştır. Genel farkındalık kapsamında halkın; taşkın öncesinde, taşkın sırasında veya sonrasında sunulan önlemlerden, stratejilerden ve uygulanan politikalardan ne kadar haberdar olduğu ölçülmüştür. Erken uyarı farkındalığı kapsamında ise; halkın erken uyarı sistemlerinden beklentileri ve bu konudaki bilinç düzeyleri incelenmiştir. Kişinin erken uyarı alması ya da almaması durumunda harekete geçme eğilimi ise bir olay ağacı üzerinde değerlendirilmiş olup, harekete geçmenin bağlı olduğu faktörler incelenmiştir. 


\subsection{Taşkın Farkındalığı}

Halkın taşkın öncesi farkındalığını ve hazırlı olma seviyesini yükseltmek oldukça önemlidir. Son yıllarda, taşkın riski olan bölgelerde taşkın olaylarına hazırlıklı olma ve taşkın farkındalığını araştıran birçok çalışma yapılmaktadır. Çoğu araştırma, taşkın farkındalığının riskli bölgede yaşayan halkın sosyo-demografik özellikleri ile ilişkili olduğunu belirtmektedir (Lindell ve Perry 2000; Kreibich vd. 2005). Bu özellikler arasında, yaş, medeni durum, evde yaşayan çocukların varlığı, gelir durumu, eğitim gibi konular için önemli korelasyonlar belirlenmiştir. Bu değisşkenlerle birlikte, taşkın risk farkındalığı seviyesinin ayrıca bazı kişisel ve psikolojik faktörler, önceki afet deneyimi, kişilik özellikleri, hazırlıklı olma için duyulan sorumluluk ve gelecekteki bir felaket için endişe düzeyi gibi değişkenlerle de ilişkili olduğunu gösteren çalışmalar da mevcuttur (Norris vd. 1999; Zaleskiewicz vd. 2002).

\subsection{Taşkın Erken Uyarı Sistemleri}

Taşkın anında meydana gelecek olan kayıpların, özellikle de can kayıplarının azaltılması amacıyla yapılması gereken en önemli konu, taşkın tahmin ve erken uyarı sistemlerinin oluşturulmasıdır (Durmuş 2020). Uyarı sistemleri, yaklaşmakta olan taşkını tahmin edip, bu bilgileri risk altındaki kişilere vererek, tehlikede olanların karar vermelerini ve harekete geçmelerini sağlar. Bu tanım, basit gözükse de uyarı sistemleri karmaşıktır. Çünkü mühendislik, teknoloji, haber medyası gibi birçok uzmanlık ve kamu kuruluşunu birbirine bağlar. En etkili uyarı sistemleri ekstrem olayların tespiti, tehlike bilgilerinin yönetimi ve halkın müdahalesinin alt sistemlerini entegre etmektedir. Bu ilişkiler planlama, pratik ve eğitim de dahil olmak üzere hazırlık yoluyla sağlanır (Sorensen 2000). Etkili taşkın tahmini ve erken uyarı sistemleri taşkın olayından önce ek hazırlık süresi sağlaması yönünden taşkın riski yönetiminin önemli bir parçasıdır (Thiemig ve Gadain 2011). Yer gözlem istasyonlarından, uydu sistemlerinden ve radarlardan temin edilen veriler, erken uyarı sisteminin temel bilgi kaynaklarını oluşturmaktadır. Bu sistemlerin her birinden elde edilecek yağış verileri birbirleri ile karşılaştırılarak daha sağlıklı ve güvenilir verilerle daha kaliteli bir erken uyarı sistemi oluşturulur (Sarıcan 2013).

\subsection{Türkiye'de Taşkın Erken Uyarı Sistemleri ve Sorumlu Kuruluşlar}

Türkiye'de taşkın tahmin ve erken uyarı sistemlerinin geliştirilmesine yönelik çok sayıda girişimde bulunulmasına rağmen bugüne kadar etkin ve tam fonksiyonel bir taşkın erken uyarı sistemi henüz kurulamamıştır. İlgili kurumlar tarafından yapılan çalışmalar çoğunlukla bölgesel ölçekte kalmıştır. Projeler genellikle büyük taşkın olaylarının ardından felaketin yaşandığı bölgeye yönelik tasarlanmış, ulusal ölçekte bir eylem planı geliştirilememiştir. Mevcut projeler ise, geliştirilen sistemlerin teknik altyapı ve personel eksikliği gibi çeşitli nedenlerden dolayı sürdürülememiştir.

Türkiye'de, yapısal taşkın kontrolü esaslı önlemler almakla sorumlu olan başlıca devlet kuruluşu Devlet Su İşleri Genel Müdürlüğ̈̈’dür (DSI). Bunun yanında Belediyelerin de dere ıslahı görev, yetki ve sorumlulukları vardır. Risk yönetimi ve zarar azaltma planlarını yapmak veya yaptırmak, afet ve acil durum bölgelerini tespit etmek, hasar tespiti yapmak ve önleyici tedbirleri ilan etmek ve ç̧eşitli eğitim ve tatbikatlar düzenlemek Afet ve Acil Durum Yönetimi Başkanlığı'nın (AFAD) görev ve sorumluluğu altındadır. Taşkın Yönetim Planlarını hazırlamak Su Yönetimi Genel Müdürlüğü'nün görevidir. Çeşitli meteorolojik ve hidrolojik verilere dayanarak olası bir taşkın tehlikesine karşı erken uyarılar yapmak ise Meteoroloji Genel Müdürlüğü (MGM) tarafından yapılmaktadır.

\section{Materyal ve Yöntem}

\section{1. Çalışma Alanı}

Çalışma alanının yer aldığı Doğu Karadeniz Havzası topoğrafik yapısı nedeniyle taşkınlara sık sık maruz kalmaktadır. Oluşan taşkınlarda, yerleşimlerin genellikle taşkın alanlarında bulunmasından ötürü birçok can kaybı, yaralanma ve maddi zararlar oluşmaktadır. Doğu Karadeniz Havzası'nda yaşanan bu taşkınların gerek ekonomik gerek can kaybı açısından boyutu, fiziki ve iklimsel koşulları nedeniyle Türkiye'deki diğer havzalardan daha fazladır (Yüksek vd. 2013). Son 90 yıllık sürede meydana gelen taşkın ve taşkının tetiklediği heyelanlar sebebiyle 644 kişi hayatını kaybetmiştir.

Çalışma alanı, Trabzon İlinin 45 km batısında bulunan ve 2019 itibari ile 23328 nüfuslu Beşikdüzü İlçesidir. Doğusunda Vakfikebir, batısında Eynesil, güneyinde Şalpazarı ve Tonya İlçeleriyle birlikte kuzeyinde tamamen Karadeniz bulunmaktadır. İlçenin yüzölçümü $121 \mathrm{~km}^{2}$ ve nüfusu 2018 yılı itibariyle 22.630'dur. Beşikdüzü ilçe merkezi yerleşim olarak dere yatakları üzerine inşa edilmiştir. İlçenin içinden beş adet dere geçmektedir ve bu dereler yerleşim yeri ve tarım arazilerinde taşkın zararlarına sebep olmaktadır (Şekil 1). 2000-2010 yılları arasında oluşan taşkın zararları; Takazlı Deresi, Tümen Deresi, Çavuşlu Deresi, Kurbağalı Deresi ve Çamlık Deresi yağış havzalarındaki nüfusu \%59 oranında azaltmıştır (DSİ 2016). 


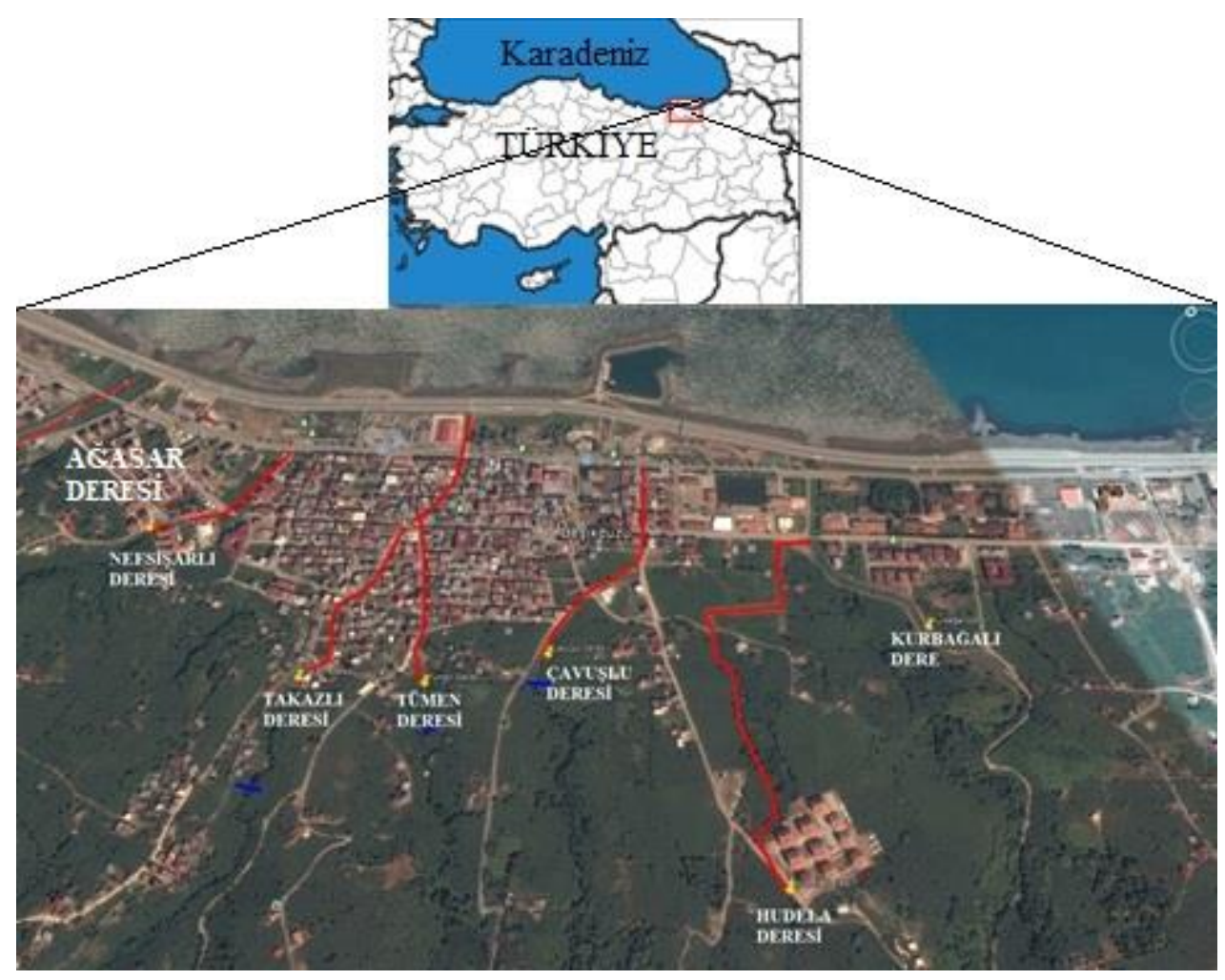

Şekil 1: Trabzon ili Beşikdüzü ilçe merkezindeki derelerin genel vaziyet planı

\subsection{Kullanılan Veriler}

\subsubsection{AGI Verileri}

Çalışma alanında DSİ'ye ait en az 15 yıllık veri ölçümü bulunan Akım Gözlem İstasyonları (AGİ) belirlenmiş ve yıllık maksimum akım ölçümleri $\left(\mathrm{m}^{3} / \mathrm{s}\right)$ elde edilmiştir. Çalışmada kullanılan AGİ'lere ait bilgiler ve gözlem süreleri DSİ'den alınmış ve Tablo 1'de gösterilmişsir.

Tablo 1: Çalışmada kullanılan AGi'lere ait veriler

\begin{tabular}{|c|c|c|c|c|}
\hline İstasyon No & İstasyon Ad1 & Drenaj alanı $\left(\mathrm{km}^{2}\right)$ & $\operatorname{Kot}(\mathrm{m})$ & Gözlem Süresi (yıl) \\
\hline DSİ/22-01 & Kürtün & 2750,00 & 480 & 39 \\
\hline DSİ/22-09 & Torul & 1900,40 & 925 & 38 \\
\hline $\mathrm{DSI} / 22-13$ & Süttaş1 & 124,85 & 188 & 25 \\
\hline $\mathrm{DSI} / 22-28$ & Bahadırlı & 191,40 & 17 & 39 \\
\hline DSİ/22-40 & Eymür & 3132,80 & 120 & 32 \\
\hline $\mathrm{DSI} / 22-58$ & Cücenköprü & 162,70 & 300 & 29 \\
\hline DSİ/22-73 & Tuğlacık & 397,90 & 400 & 25 \\
\hline $\mathrm{DSI} / 22-80$ & Gökçebel & 296,90 & 750 & 25 \\
\hline DSİ/22-83 & Gümüşkaya & 410,80 & 1150 & 16 \\
\hline DSİ/22-84 & İkisu & 149,60 & 1375 & 22 \\
\hline DSİ/22-87 & Hasanşıh & 256,80 & 355 & 28 \\
\hline
\end{tabular}

\subsubsection{Beşikdüzü Taşkını Verileri}

20 Eylül 2016 tarihi gece saatlerinde başlayan ve şiddetini artırarak devam eden sağanak yağışlar sonucunda, 21 Eylül 2016'da kapalı menfezlerin ve geçiş yapılarının, ağaçlar ve gelen sedimentlerle tıkanmasıyla Beşikdüzü ilçe merkezinde ciddi mal kayıplarının olduğu büyük bir taşkın meydana gelmiştir. İlçe merkezinin memba kesiminde ise heyelan kaynaklı 3 can kaybı yaşanmıştır. Taşkın kontrol tesisleri tıkanma nedeniyle dolu kesit akmakta olup, menfezlerin rüsubat, ağaç ve köklerle dolarak taşması sonucunda ilçe merkezinin tamamına yakını sular altında kalmıştır (Şekil 2). Taşkın sahalarına 12 saatte 291 mm yağış düşmüştür. 

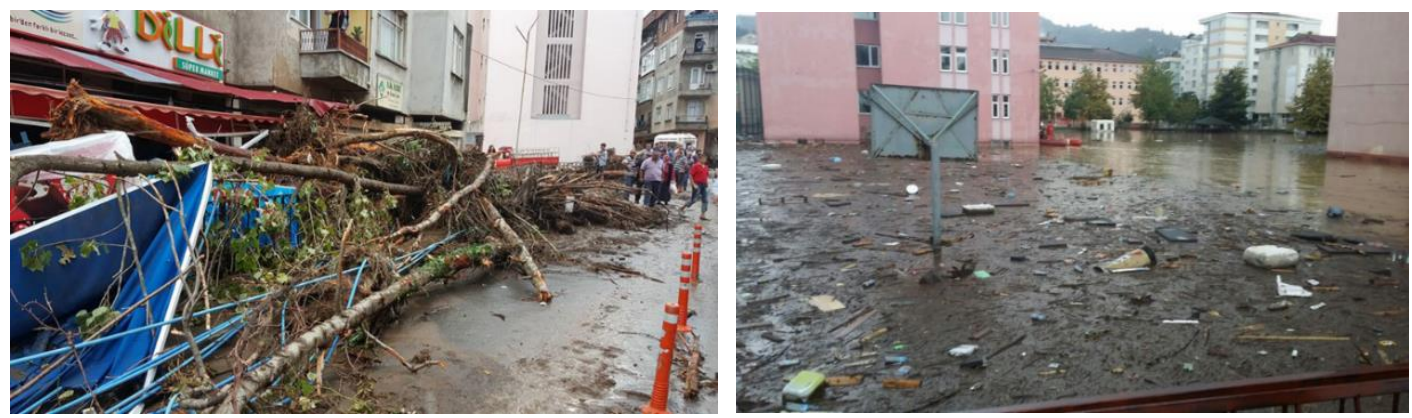

Şekil 2: Yukarı havzadan mansaba sürüklenen ağaçlar ve sular altında kalan okul bahçesi (DSI 2016)

Saat 15.00'te Ağasar Deresi 22-120 Ambarlı Akım Gözlem İstasyonundaki debi değeri, cetvelden ölçülen $355 \mathrm{~cm}$ su seviyesine göre $303 \mathrm{~m}^{3} / \mathrm{s}$ olarak hesaplanmıştır. Tablo 2'de derelerde taşkın seviyelerinden elde edilen yaklaşı debi değerleri ve değişik frekanslarda DSİ tarafından hesaplanan taşkın debileri verilmektedir. Tabloda da görüldüğü gibi, taşkın anında saat 15.00 ’te Ağasar Deresinden geçen debi değeri, $\mathrm{Q}_{100}$ değerine yakındır.

Tablo 2: Trabzon Beşikdüzü Ağasar Deresi mansap debi değerleri

\begin{tabular}{cccccccccc}
\hline \multicolumn{7}{c}{ Farklı Tekerrür Sürelerine Ait Taşkın Debi Değerleri $\left(\mathrm{m}^{3} / \mathrm{s}\right)$} \\
\hline Alan $\left(\mathrm{km}^{2}\right)$ & Gerçekleşen Taşkın & $\mathrm{Q}_{2}$ & $\mathrm{Q}_{5}$ & $\mathrm{Q}_{10}$ & $\mathrm{Q}_{25}$ & $\mathrm{Q}_{50}$ & $\mathrm{Q}_{100}$ & $\mathrm{Q}_{500}$ & $\mathrm{Q}_{1000}$ \\
\hline 130 & 303,00 & 52,46 & 96,72 & 134,96 & 194,45 & 247,35 & 308,44 & 428,40 & 480,19 \\
\hline
\end{tabular}

\subsection{Yöntem}

Öncelikle yaşanan taşkının kaç yıl tekerrür süreli taşkın debisine karşılık geldiğini belirlemek için L momentler yöntemi ile çeşitli tekerrür süreli taşkın debileri hesaplanmıştır. Hesaplanan debiler yaşanan söz konusu afet anındaki taşkın debisi ile karşılaştırılmış ve ilçenin taşkınlardan zarar görebilirlik riski farklı tekerrür süreli debiler için irdelenmiştir. Daha sonra taşkın riski farkındalık, insanların harekete geçme eğilimleri ve erken uyarı sistemindeki eksiklikleri belirlemek adına bölge halkıyla 'Taşkın Farkındalık ve Taşkın Erken Uyarı Anında İnsan Davranışları' üzerine anket yapılmıştır. $\mathrm{Bu}$ doğrultuda, taşkın farkındalığı ve erken uyarı sistemlerinin etkinliği değerlendirilmiştir.

\subsubsection{L-Momentler Yöntemi}

Beşikdüzü Havzası'nın L-momentler yardımıyla taşkın frekans analizinde; AGİ'lere ait olasılık ağırlıklı moment ve Lmoment değerleri hesaplanmıştır. Hosking (1986) tarafından geliştirilen L-momentler; parametre tahmini, bölgeselleştirme ve dağılım tanımlama ile ilgili çeşitli problemleri çözmede yaygın olarak kullanılmaktadır. L-momentler olasılık ağırlıklı momentler yönteminin doğrusal bir fonksiyonu olup olasılık ağırlıklı momentleri cinsinden aşağıdaki gibi ifade edilebilirler (Gebeyehu 1989):

$L_{r+1}=(-1)^{r} \sum_{k=0}^{r}(-1)^{r-k}\left(\begin{array}{c}r \\ k\end{array}\right)\left(\begin{array}{c}r+k \\ k\end{array}\right) M_{1,0, k}$

L-momentler;

$r=0$ ise $L_{1}=M_{100}$

$r=1$ ise $L_{2}=M_{100}(2 M)_{101}=2 M_{110}-M_{100}$

$r=2$ ise $L_{3}=M_{100}(6 M)_{101}+6 M_{102}=6 M_{120}-6 M_{110}+M_{100}$

$r=3$ ise $L_{4}=M_{100}-12 M_{101}+30 M_{102}-20 M_{103}=20 M_{130}-30 M_{120}+12 M_{110}-M_{100}$

Yüksek mertebeden momentlerde ölçümler birbirinden bağımsızlaştırılırsa L-moment oranları aşağıdaki gibidir (Vogel ve Fennessey 1993).

$\mathrm{r}=3,4, \ldots$, ise $\mathrm{t}_{\mathrm{r}}=\frac{\mathrm{L}_{\mathrm{r}}}{\mathrm{L}_{2}}, \mathrm{t}=\frac{\mathrm{L}_{2}}{\mathrm{~L}_{1}}$

L-momentler $\left(\mathrm{L}_{1}\right)$ ve $\left(\mathrm{L}_{2}\right)$, L-moment oranları L-cv(t), çarpıklık katsayısı (t3), basıklık (kurtosis) katsayısı (t4), olasılık dağılımını özetlemek için en çok kullanılan parametrelerdir. $L_{1}$ dağılımı yer parametresini, $L_{2}$ dağılımı ise ölçek parametresini temsil etmektedir (Hosking ve Wallis 1988; Hosking 1990). 
Bölgesel taşkın frekans analizinde, homojen istasyonların ve dolayısıyla homojen bölgelerin tanımlanması ve havzaya tek bir frekans dağılımının uygulanması gerekmektedir. Bunun yapılabilmesi için çalışma alanının homojen olması ve istasyonların homojenlik koşulunu sağlaması gerekmektedir. Homojenlik şartı; bölgeye aynı frekans dağılımının uygulanabilirliği anlamına gelmektedir. Bölgesel homojenliği test etmek için iki istatistik öne sürülmüştür. Bunlar; uyumsuzluk ve heterojenlik ölçüsüdür. Homojenlik analizinden sonraki aşama bölge için en uygun dağılımı hesaplamaktır. Bölge için tek bir dağılımın kabulü esasına göre yapılan test $Z$ uygunluk testidir. Hesaplanan tekerrür tahminlerinin doğruluğunun kabul edilebilir düzeyde olup olmadığı Monte Carlo benzeşimi ile hesaplanır. Her istasyon için, göreceli taraflılık değerleri (rölatif bias) ve \%5-\%95 alt ve üst güvenilirlik bant sınırları elde edilir. Bölge bazında bu değerlere ek olarak, ortalama hata değerleri de hesaplanır. Homojenlik analizi, Z testi ve tekerrür debilerinin hesabının detaylı bilgileri (Hosking ve Wallis 1993; Hosking ve Wallis 1997; Şorman ve Okur 2000; Seçkin vd. 2013; Anılan 2014) mevcut literatürde bulunmaktadır.

Bu çalışmada, Beşikdüzü Havzası'nın L-momentler yardımıyla taşkın frekans analizinde; AGİlere ait olasılık ağırlıklı moment ve L-moment değerleri hesaplanmıştır. Yöntemin detaylı bilgileri (Hosking ve Wallis 1993; Hosking ve Wallis 1997; Anılan 2014)'te bulunmaktadır. Bölgenin homojenliği L-momentler yöntemine dayalı iki istatistik olan uyumsuzluk ve heterojenlik ölçüsü ile test edilmiştir. Her bir istasyon için elde edilen $\mathrm{D}_{\mathrm{i}}$ değerleri uyumsuzluk ölçüsü değerleri ile karşılaştırılarak istasyonların homojenliği test edilmiştir. Heterojenlik ölçüsü hesabında $V_{1}, V_{2}$ ve $V_{3}$ 'e bağlı $\mathrm{H}_{\mathrm{i}}$ değerleri belirlenmiştir. Xtest programı kullanılarak Z değerleri hesaplanmıştır. Uygun bulunan dağılımlar içinde 0'a en yakın olan dağılım, en uygun dağılım olarak belirlenmiştir. Bölge için en uygun dağılım belirlendikten sonra çeşitli yineleme aralıklarına karşılık gelen taşkın debilerinin tahmini yapılmıştır. Program içinde yer alan benzeşim sayısı (NSIM) ve her benzeşimde tekrarlanma sayısı (NREP) değeri bu çalışmada 500 alınmıştır. Sabitlerin seçilmesinde literatürde kullanılan değerler dikkate alınmıştır (Hosking ve Wallis 1997). Hesaplanacak karakteristik değer sayısı (NQ) 6 ve bu değere bağlı olarak aşılmama olasılıkları (FVAL) 0.5, 0.8, 0.9, 0.96, 0.98, 0.99 olarak girilmiştir. 0.5, 0.8, 0.9, $0.96,0.98,0.99$ olarak girilen aşılmama olasılıkları $\mathrm{T}=2,5,10,25,50$ ve 100 yıl yineleme sürelerine karşılık gelmektedir. Verilerin girilmesinden sonra bölge için uygun bulunan dağılıma göre seçilen yineleme aralıklarına göre karakteristik değerler hesaplanmıştır. Bunun için program içerisinde Elde edilen karakteristik değerler aşılmama olasıllkları ile çarpılarak her bir istasyonun seçilen yineleme aralıklarına karşılık gelen taşkın debileri hesaplanmıştır. Bölgesel tek dağılıma karşılık elde edilen karakteristik değerlerin doğrulukları aynı program içerisinde incelenmiştir. Karakteristik değerlerin doğrulukları incelenirken Monte Carlo benzeşimi yapılarak her istasyonun BIAS ve RMSE değerleri elde edilmiştir.

\subsubsection{Sosyal Çalışma}

Taşkın farkındalığını ve risk bilincini, erken uyarı farkındalığı ve erken uyarı sonrasında insan farkındalığını ölçmek adına 21 Eylül 2016 tarihindeki taşkın felaketini yaşayan 100 kişiyle bir anket çalışması düzenlenmiştir. Yaşanan deneyimin ilerde yaşanması muhtemel taşkınlarda farkındalık yaratıp yaratmayacağı hakkında bilgi sahibi olmak için katılımııların çoğunun, taşkını bizzat yaşayan, taşkından hasar görmüş kişiler olmasına ayrıca dikkat edilmiştir. Taşkının ilçe merkezinde meydana geldiği göz önünde bulundurulduğunda, olaydan en çok hasar gören kesim olan dükkân sahiplerinin katılımı çoğunluğu sağlanmıştır. Dükkân sahiplerinin çoğunun erkek olması ve bazı kadınların ankete katılma çekincesinden dolayı ile katılımcıların çoğunluğunu erkekler oluşturmaktadır. İlçe merkezindeki kahvehaneler, öğretmen evi, taksi durağı, belediyeler ve okullar anket için ziyaret edilen yerler arasındadır. Katılımcılara ait cinsiyet, yaş aralığı ve eğitim düzeyleri parametreleri de toplanarak Tablo 3'te verilmiştir.

Tablo 3: Katılımcıların yaş, cinsiyet ve eğitim düzeyleri dağılımı

\begin{tabular}{cccccc}
\hline Yaş Aralığ1 & Yüzde (\%) & Cinsiyet & Yüzde (\%) & Eğitim Düzeyi & Yüzde (\%) \\
\hline $15-24$ & 42 & Kadın & 42 & İlkokul & 5 \\
$25-34$ & 9 & Erkek & 58 & Ortaokul & 2 \\
$35-49$ & 23 & & Lise & 69 \\
50 ve üzeri & 26 & & Üniversite & 23 \\
\hline
\end{tabular}

Anket soruları, taşkın farkındalığını, taşkın erken uyarı farkındalığını ve erken uyarı sonrası insan davranışını ölçmek amaçlarını kapsayacak şekilde 3 kısımdan oluşturulmuştur (Tablo 4). Her bir bölümdeki sorular kişinin bireysel farkındalığı, afetlerle baş etme yeterliliği, bilgi düzeyi ve bireysel yeterliliğinin saptanması hedeflenmiştir (Anılan ve Yüksek 2017).

Anketin birinci bölümündeki sorular, sık sık taşkın felaketiyle karşılaşan halkın taşkın farkındalığını belirlemek amacına yöneliktir. Bunun için öncelikle kendilerinin risk altında olduklarını düşünüp düşünmedikleri sorularak bireysel farkındalıkları yorumlanmıştır. Daha sonra, yaşadıkları büyük taşkından sonra olası taşkınlara karşı kendileri veya başkaları tarafından herhangi bir önlem alınıp alınmadığı sorularak risk farkındalığı ve mücadele yeterliliği ölçülmüştür. Yine bu amaçla ve aynı zamanda bilgi düzeyini de ölçmek için taşkın felaketlerinin önlenip önlenemeyeceği ve bu önlemleri almaktan kimin sorumlu olduğu sorulmuştur. Anketin ikinci kısmı, taşkın erken uyarı farkındalığını 
belirlemeye yönelik olup; bireylerin erken uyarı anında ne yapılması gerektiğini bilip bilmedikleri sorgulanmıştır. Aynı zamanda uyarı ve planlamalar konusunda eğitim ya da bilgilendirme alma istekleri irdelenmiştir. Kişilerin hangi uyarı kaynağına daha çok güvendikleri ve nasıl uyarılmak istedikleri araştırılmış, bu uyarıyı en az ne kadar süre önce almaları istendiği sorulmuştur (Karaman 2018). Bu soruyla, kişinin ihtiyacı olan minimum hazırlık süresinin ölçülmesi ve bu süre zarfinda kurtarılabilecek kayıpların belirlenmesi hedeflenmiştir. Anketin üçüncü kısmı, bölgedeki erken uyarı sistemlerinin kişilerin harekete geçmesi üzerindeki etkisi ve bu uyarılara karşı güven düzeyini ölçmeyi amaçlamaktadır. Bu amaçla, katılımcılara yaşadıkları 21 Eylül 2016 Beşikdüzü taşkını felaketinden önce herhangi bir erken uyarı alıp almadıkları sorusu yöneltilmiştir. Bu soruyla mevcut erken uyarı sistemlerine dikkat çekmek hedeflenmiştir. Daha sonrasında erken uyarı aldıklarında kendilerini risk altında görüp görmedikleri sorularak, uyarı kaynağına olan güveni ölçmek adına uyarıya çevreden veya başkasından onay arayıp aramadıkları sorulmuştur. Ardından erken uyarı sonrasında risk altında hisseden bireyin önlem olarak harekete geçme eğilimi incelenmiştir.

Tablo 4: Anket soruları, amaçları ve cevap şekilleri

\begin{tabular}{lll}
\hline Soru & Amaç & Cevap şekli \\
\hline 1. Bölüm (taşkın farkındalık) & & \\
\hline 1. Taşkın riski altında olduğunuzu düşünüyor musunuz? & $\begin{array}{l}\text { bireysel farkındalık } \\
\text { baş etme yeterliliği }\end{array}$ & E / H \\
2. Taşkından sonra önlem aldınız mı veya alındı mı? & E / H, AU \\
3. Sizce taşkınlar önlenebilir mi? Nasıl? & bilgi düzeyi & E / H, AU \\
4. Sizce taşkınların önlenmesinden kim sorumludur? & AU \\
\hline 2. Bölüm (erken uyarı farkındalı) & ne yapacağını bilme & AU \\
\hline 5. Taşkın anında harekete geçince ne yaptınız? & bilgi düzeyi & E / H \\
6. Erken uyarı hakkında bilgi sahibi misiniz? & bilinç & E / H \\
7. Bilgilendirme veya eğitim almak ister misiniz? & etki tespiti & AU \\
8. Erken uyarıyı hangi yolla almayı tercih edersiniz? & ihtiyaç tespiti & AU \\
9. Harekete geçmek için ihtiyacınız olan süre nedir? & bireysel yeterlilik & AU \\
10. Bu sürede oluşabilecek hangi zararları önlersiniz? & & \\
\hline 3. Bölüm (erken uyarı sonrası insan davranışı) & tespit & E / H \\
\hline 11. Erken uyarı oldu mu? & tespit & AU \\
12. Erken uyarıyı hangi yolla aldınız? & risk algısı & E / H \\
13. Risk altında olduğunu anladınız mı? & güven düzeyi & E / H \\
14. Erken uyarıa güvendiniz mi? & bilgi düzeyi & E / H \\
15. Uyarıdan sonra ne yapacağınızı biliyor muydunuz? & tespit & E / H \\
16. Önlem için harekete geçtiniz mi? & & \\
\hline
\end{tabular}

*E/H: evet/hayır; AU: açık uçlu

\section{Bulgular}

\section{1. Çeşitli Tekerrür Sürelerine Ait Taşkın Debileri Tahmini}

İstasyonların olasılık ağırlıklı momentleri ve L-momentleri Excel yardımıyla hesaplanmıştır. Daha sonra L-momentler vasıtasıyla L-moment oranları ve uyumsuzluk ölçüsü $\left(\mathrm{D}_{\mathrm{i}}\right)$ değerleri elde edilmiş ve sonuçlar Tablo 5'te verilmiştir. Uyumsuzluk ölçüsü hesabında istasyonların $D_{i}$ değerlerinin kritik değer şartını sağladığı görülmüştür. Heterojenlik ölçüsü için kullanılan Xtest programının sonucunda elde edilen $\mathrm{V}_{1}, \mathrm{~V}_{2}$ ve $\mathrm{V}_{3}$ 'e göre hesaplanan $\mathrm{H}_{1}, \mathrm{H}_{2}$ ve $\mathrm{H}_{3}$ değerleri dikkate alınarak bölgenin homojen olduğu gözlemlenmiştir (Tablo 6).

Tablo 5: Istasyonların L-moment oranları ve $D_{i}$ değerleri

\begin{tabular}{|c|c|c|c|c|c|}
\hline İst. No & $\mathrm{t}$ & $t_{3}$ & $\mathrm{t}_{4}$ & $t_{5}$ & $\mathrm{D}_{\mathrm{i}}$ \\
\hline $22-01$ & 0,26434 & 0,238569 & 0,22409 & 0,148469 & 0,39 \\
\hline $22-09$ & 0,274083 & 0,368907 & 0,368196 & 0,246082 & 1,45 \\
\hline $22-13$ & 0,234106 & 0,327695 & 0,330526 & 0,176618 & 0,78 \\
\hline $22-28$ & 0,364329 & 0,377735 & 0,326734 & 0,225652 & 0,98 \\
\hline $22-40$ & 0,219673 & 0,118512 & 0,039906 & $-0,04023$ & 1,98 \\
\hline $22-58$ & 0,301587 & 0,382998 & 0,22699 & 0,098158 & 1,48 \\
\hline $22-73$ & 0,298109 & 0,258148 & 0,182527 & 0,164783 & 0,19 \\
\hline $22-80$ & 0,357793 & 0,263123 & 0,106476 & 0,047666 & 1,17 \\
\hline $22-83$ & 0,294051 & 0,348703 & 0,2585 & 0,142778 & 0,25 \\
\hline $22-84$ & 0,256387 & 0,245948 & 0,255902 & 0,153802 & 0,56 \\
\hline $22-87$ & 0,420191 & 0,450675 & 0,221117 & 0,087578 & 1,77 \\
\hline
\end{tabular}


Tablo 6: Havzaların heterojenlik ölçüsü

\begin{tabular}{llc}
\hline Heterojenlik Ölçüsü (Benzeşim Sayısı=500) & \\
\hline & Gözlenen değerlerin Grup L-Cv'lerinin standart sapması & 0,0581 \\
$\mathrm{H}_{1}$ & Grup L-Cv'lerinin standart sapmasının benzeşim ortalamaları & 0,0467 \\
& Grup L-Cvl'erinin standart sapmasının benzeşimlerinin standart sapmaları & 0,0129 \\
& Standartlaştırılmış H değerleri & 0,89 \\
\cline { 2 - 3 } & Gözlenmiş ortalamanın L-Cv/L-Cs mesafesi & 0,0963 \\
& Ortalama L-Cv/L-Cs mesafesinin benzeşim ortalaması & 0,1025 \\
$\mathrm{H}_{2}$ & Ortalama L-Cv/L-Cs mesafesinin benzeşim standart sapması & 0,0232 \\
& Standartlaştırılmış H $\mathrm{H}_{2}$ değerleri & $-0,27$ \\
\cline { 2 - 3 } & Gözlenmiş ortalamanın L-Cs/L-Ck mesafesi & 0,1183 \\
& Ortalama L-Cs/L-Ck mesafesinin benzeşim ortalaması & 0,1291 \\
$\mathrm{H}_{3}$ & Ortalama L-Cs/L-Ck mesafesinin benzeşim standart sapması & 0,0291 \\
& Standartlaştırılmış $\mathrm{H}_{3}$ değerleri & $-0,37$ \\
\hline
\end{tabular}

Homojen bölge için kullanılacak en uygun dağılım, Z uygunluk ölçüsü değeri ile hesaplanmıştır. $(|Z|\langle 1,645)$ şartını sağlayan dağılımlar o bölge için uygun olarak kabul edilmiştir. Xtest programı ile hesaplanan Z uygunluk ölçüsü değeri $-0,11$, Genelleştirilmiş Lojistik Dağılım için koşulu sağlamış ve diğer dağılımlar içinde 0 değerine en yakın sonucu vermiş̧ir. Tablo 7'de görüldüğü üzere Genelleştirilmiş Lojistik Dağılım için $Z$ değeri $-0,11$ ile bölge için en uygun dağılım olarak kabul edilmiştir.

Tablo 7: Havza uygunluk ölçüsü değerleri

\begin{tabular}{lll}
\hline Dağılımlar & $T_{4}{ }^{\text {DIST }}$ & $\mathrm{Z}^{\text {DIST }}$ \\
\hline Log Normal (LN) & 0,197 & $-1,50$ \\
Gen. Ekstrem Değer (GEV) & 0,220 & $-0,86$ \\
Gen. Lojistik (GLO) & 0,246 & $-0,11$ \\
Pearson Tip III (PE3) & 0,159 & $-2,60$ \\
\hline
\end{tabular}

Z testine göre bölge için en uygun dağılım olarak belirlenen GLO dağılım için çeşitli yineleme aralıklarına karşılık gelen karakteristik değerler Xtest programından hesaplanıp Xsim programı ile benzeşim yapılarak her bir istasyonun değişim katsayıları programa yazılmıştır. Bu parametreler için $\mathrm{T}=2,5,10,25,50$ ve 100 yıl süreli yineleme aralıklarına karşıllk gelen karakteristik değerler Tablo 8'de gösterilmiştir.

Tablo 8: GLO dağıımına göre istasyonlar için çeşitli yineleme aralıklarına karşılık gelen karakteristik değerler

\begin{tabular}{lllllll}
\hline \multirow{2}{*}{ İstasyon Ad 1} & \multicolumn{7}{c}{ Yineleme Aralıkları } & \multicolumn{7}{c}{ 10 } & 5 & 25 & 50 & 100 \\
\cline { 2 - 6 } & 2 & \multicolumn{7}{c}{ Karakteristik Değerler } \\
\cline { 2 - 7 } & 0,859 & 1,299 & 1,644 & 2,137 & 2,544 & 2,986 \\
$22-01$ & 0,849 & 1,319 & 1,687 & 2,213 & 2,648 & 3,119 \\
$22-13$ & 0,875 & 1,265 & 1,570 & 2,007 & 2,368 & 2,759 \\
$22-28$ & 0,805 & 1,412 & 1,887 & 2,567 & 3,128 & 3,737 \\
$22-40$ & 0,883 & 1,248 & 1,535 & 1,945 & 2,284 & 2,650 \\
$22-58$ & 0,839 & 1,341 & 1,734 & 2,297 & 2,762 & 3,266 \\
$22-73$ & 0,841 & 1,337 & 1,726 & 2,282 & 2,742 & 3,239 \\
$22-80$ & 0,809 & 1,405 & 1,871 & 2,539 & 3,090 & 3,688 \\
$22-83$ & 0,843 & 1,333 & 1,716 & 2,265 & 2,718 & 3,209 \\
$22-84$ & 0,863 & 1,290 & 1,624 & 2,103 & 2,498 & 2,926 \\
$22-87$ & 0,776 & 1,475 & 2,023 & 2,807 & 3,455 & 4,157 \\
\hline
\end{tabular}

Her bir istasyon için çeşitli yineleme aralıklarına göre hesaplanan karakteristik değerler ile o istasyonun debilerinin aritmetik ortalaması çarpımıyla debi değerleri elde edilmiş ve Tablo 9'da gösterilmiştir (Durmuş 2020). 
Tablo 9: Istasyonların $T=2,5,10,25,50$ ve 100 yıl yineleme süreli taşkın debileri

\begin{tabular}{lrrrrrrr}
\hline İstasyon & $\mathrm{Q}_{\text {ort }}$ & \multicolumn{1}{c}{$\mathrm{Q}_{2}$} & \multicolumn{1}{c}{$\mathrm{Q}_{5}$} & \multicolumn{1}{c}{$\mathrm{Q}_{10}$} & \multicolumn{1}{c}{$\mathrm{Q}_{25}$} & \multicolumn{1}{c}{$\mathrm{Q}_{50}$} & \multicolumn{1}{c}{$\mathrm{Q}_{100}$} \\
\hline $22-01$ & 257,45 & 221,15 & 334,43 & 423,25 & 550,18 & 654,96 & 768,76 \\
$22-09$ & 147,25 & 125,01 & 194,22 & 248,41 & 325,86 & 389,91 & 459,27 \\
$22-13$ & 28,18 & 24,66 & 35,65 & 44,25 & 56,56 & 66,74 & 77,76 \\
$22-28$ & 81,49 & 65,60 & 115,06 & 153,77 & 209,18 & 254,90 & 304,53 \\
$22-40$ & 347,56 & 306,90 & 433,76 & 533,51 & 676,01 & 793,83 & 921,04 \\
$22-58$ & 93,07 & 78,08 & 124,80 & 161,38 & 213,77 & 257,05 & 303,95 \\
$22-73$ & 71,48 & 60,11 & 95,56 & 123,37 & 163,11 & 195,99 & 231,51 \\
$22-80$ & 81,93 & 66,28 & 115,11 & 153,29 & 208,02 & 253,17 & 302,16 \\
$22-83$ & 67,50 & 56,90 & 89,98 & 115,83 & 152,89 & 183,46 & 216,60 \\
$22-84$ & 21,57 & 18,61 & 27,82 & 35,02 & 45,35 & 53,87 & 63,10 \\
$22-87$ & 89,90 & 69,76 & 132,60 & 181,87 & 252,36 & 310,62 & 373,73 \\
\hline
\end{tabular}

\subsection{Taşkın Debisi Tahminlerinin Beşikdüzü Taşkınıyla İrdelenmesi}

Beşikdüzü taşkınında Ağasar Deresi akım gözlem istasyonunda yapılan su seviyesi ölçümlerinde 21 Eylül 2016 günü debi $303 \mathrm{~m}$ 3/s olarak hesaplanmıştır. Çalışma alanına en yakın olan AGİ'lerden gözlem süresi en fazla olan 22-28 numaralı Fol Deresi Bahadırlı istasyonudur. Bahadırlı istasyonuna ait 100 yıl yineleme süreli taşkın debisi değeri bu çalışmada 304,53 m³ s olarak hesaplanmıştır (Tablo 9). L-momentlerle yapılan taşkın frekans analizine göre Beşikdüzü'nde meydana gelen bu şiddette bir yağışın görülme ihtimalinin, tüm standart zamanlarda 100 yılın üzerinde olduğu gözlemlenmiştir. DSİ tarafından yapılan, 22-28 numaralı Fol Deresi Bahadırlı istasyonu için çeşitli tekerrür sürelerine ait taşkın debisi hesabıyla, bu çalışmada hesaplanan taşkın debisi karşılaştırması Tablo 10'da verilmiştir (Durmuş 2020). Hesaplamalarda aynı yıllara ait yıllık maksimum debi verileri kullanılmıştır.

Tablo 10: 22-28 numaralı Bahadırlı istasyonu çeşitli tekerrür süreli debi değerleri

\begin{tabular}{lccccccc}
\hline & Uygun dă̆ 11 m & $\mathrm{Q}_{2}$ & $\mathrm{Q}_{5}$ & $\mathrm{Q}_{10}$ & $\mathrm{Q}_{25}$ & $\mathrm{Q}_{50}$ & $\mathrm{Q}_{100}$ \\
\hline DSİ & LN & 67,90 & 125,20 & 171,70 & 251,70 & 320,10 & 399,20 \\
Bu çalışma & GLO & 65,60 & 115,06 & 153,77 & 209,18 & 254,90 & 304,53 \\
\hline
\end{tabular}

\subsection{Taşkın Farkındalık Değerlendirilmesi}

Katılımcılara yöneltilen evet/hayır (E/H) sorularına verilen yanıtlar Tablo 11'de gösterilmiştir. 'Taşkınlar önlenebilir mi?' sorusuna evet cevabını verenlerin yüzdesi 69'dur. Bu cevabı verenlerin yaklaşık \%54'ü taşkın felaketlerinin önüne ancak gerekli yapısal önlemlerin alınması ile geçilebileceğini belirtmişlerdir. Alınması gereken yapısal önlemler için, barajlar ve setler kurmak, taşkın duvarları inşa etmek, ilçenin alt yapısında iyileştirmeler yapmak gibi cevaplar vermişlerdir. Katılımcıların \%8'i ise toplumun gerekli eğitim ve bilgilendirmelerle beraber risk bilincinin artırılmasının zararları önleyebileceği ya da azaltabileceği görüşündedir. Aynı zamanda taşkınların önlenebileceğini düşünen katılımcıların \%24'ü ise mevcut dere yataklarına yerleşimden kaçınmak ve menfezlerin tıkanmasını önlemek gibi yapısız taşkın tedbirleri alınabileceğini belirtmişlerdir.

Yapısız taşkın kontrolü çözümleri açısından Anılan ve Yüksek (2017) tarafından yapılan çalışma ile karşılaştırıldığında, bu çalışmada bilgi düzeyinin ve bu çözüm alternatifi için verilen cevap oranlarının daha düşük çıtığı gözlenmiştir. Anılan ve Yüksek (2017)'te ağaçlandırma için verilen \%16'lık cevap bu çalışmada katılımcılardan alınmamıştır. Taşkınların hiç önlenemeyeceği görüşünde olan katılımcılar ise \%31 oranındadır ve bunların yaklaşık \%6'sı bu durumu “Allah'ın işidir, önlenemez” şeklinde yorumlamıştır. "Taşkından sonra önlem aldınız mı veya alındı mı” sorusuna \%59 oranı ile hayır şeklinde cevap veren katılımcıların, DSİ'nin yukarı havzada taşkın sonrası yaptı̆̆ı rüsubat kontrol tesisleri hakkında bilgisi olmadığını göstermektedir.

Tablo 11: E/H sorularına verilen yanıt oranları

\begin{tabular}{lcc}
\hline Sorular & Evet (\%) & Hayır (\%) \\
\hline 1.Taşkın riski altında olduğunuzu düşünüyor musunuz? & 60 & 40 \\
2.Taşkından sonra önlem aldınız mı veya alındı mı? & 41 & 59 \\
3.Sizce taşkınlar önlenebilir mi? Nasıl? & 69 & 31 \\
6.Erken uyarı hakkında bilgi sahibi misiniz? & 19 & 81 \\
7.Bilgilendirme veya eğitim almak ister misiniz? & 46 & 54 \\
8.Erken uyarı oldu mu? & 18 & 82 \\
\hline
\end{tabular}


Taşkınların önlenebilip önlenemeyeceği konusu cinsiyete bağlı olarak değerlendirildiğinde, ankete katılan kadın katılımcıların \%62'si taşkınların önlenebileceği konusunda görüş bildirirken \%38'i taşkınların önlenemeyeceğini söylemiştir. Erkek katılımcıların ise \%74'ü taşkınların önlenebileceği fikrindedir.

Taşkınların önlenebilip önlenemeyeceği konusu yaşa bağlı olarak değerlendirildiğinde, 15-24 yaş aralığındaki katılımcıların \%71'i, 25-34 yaş aralığındaki katılımcıların \%67'si, 35-49 yaş arası katılımcıların \%65'i ve 50 yaş ve üzeri katılımcıların ise \%69'u taşkınları önlenebileceğini söylemiştir. Verilere göre 35-49 yaş arası nüfusun, genç nüfusa oranla daha bilinçli yanıt verdiği gözlemlenmiştir. 50 yaş ve üzeri katılımcılardan taşkınların önlenemeyeceği yönünde cevap verenlerin çoğu bu duruma karamsar baktıklarını ifade etmiştir.

Taşkınların önlenebilip önlenemeyeceği konusu eğitim düzeyine bağlı olarak değerlendirildiğinde, ilkokul mezunu olanların \%80'i, ortaokul mezunu olanların \%50'si, lise mezunu olanların \%68'i, üniversite mezunu olanların \%69'u ve doktorasını yapmış olanların \%100'ü taşkınların önlenebilir olduğu görüşündedir. Taşkınların önlenebilirliği sorusuna verilen yanıtların eğitim düzeyiyle olan ilişkisi incelendiği zaman, üniversite ve lise mezunlarının bu konuya yaklaşımlarının ortaokul mezunu olanlara göre daha bilinçli olduğu gözlemlenmiştir.

Büyükşehirlerin bulunduğu illerde DSİ ile bir protokol yapılmadığı hallerde taşkın kontrolünden DSİ, dere 1slahlarından ise DSİ ve büyükşsehir belediyeleri ortak sorumludur. Trabzon ilinde bu manada bir protokol bulunmamaktadır. Bunun yanında taşkına özellikle sebebiyet veren kapalı kesitlerin, daraltıcı yapıların, hafriyat dökümlerinin önlenmesi ve kaldırılmasından belediyeler ve ilgili mülki idare amirleri sorumludur. İmar izinleri ise Büyükşehir Belediyelerinin sorumluluğunda olup, taşkın yönüyle DSİ'den görüş alınmak zorundadır. Bu bilgiler 1şığında, halkın bilgi düzeyini ölçmek adına sorulan taşkınların önlenmesinden kimin sorumlu olduğu sorusuna \%50 oranında 'belediyeler' cevabı verilmiştir.

Bu cevabı verenlerin eğitim seviyeleri incelendiğinde \%72'sinin lise mezunu, \%16'sının üniversite mezunu, kalan \%12'lik kısmın ise ortaokul veya ilkokul mezunu olduğu saptanmıştır. DSİ'nin sorumluluğu olduğunu düşünenler ise katılımcıların \%14'ünü oluşturmaktadır. Bu yanıtı verenlerin \%71'i lise mezunu, \%29'si ise üniversite mezunudur. Soruya hem belediye hem DSİ yanıtını verenler ise katılımcıların \% 7'sini oluşturmaktadır. Bunların \%57'si lise mezunu, \%29'u üniversite mezunu kalan \%14'ü ise ilkokul mezunudur. Taşkınların önlenmesinden sorumlu kurum ve kuruluşlar hakkında bilgi sahibi olmayan katılımcılar ise \%8 oranındadır. Bu katılımcıların \%13'ü üniversite, \%87'si lise mezunudur. Sorunun cevabına kurum ve kuruluşlar haricinde insan faktörünü de ekleyen katılımcılar ise \%7 oranındadır. Bunlardan lise mezunu olanlar \%86 oranında iken \%14'sinin eğitim düzeyi doktoradır (Şekil 3). Ayrıca taşkınların önlenebilmesinden sorumlu diğer kurum ve kuruluşlara \%14 oranında AFAD, valilik, kaymakamlık gibi cevaplar alınmıştır. Verilen yanıtlar göz önünde bulundurulduğunda, katılımcıların yarısından fazlasının taşkın riskini azaltmada ve zararlarını önlemede sorumluluk sahibi kuruluşların başında DSİ’nin olduğunun bilincinde olmadığını göstermektedir.

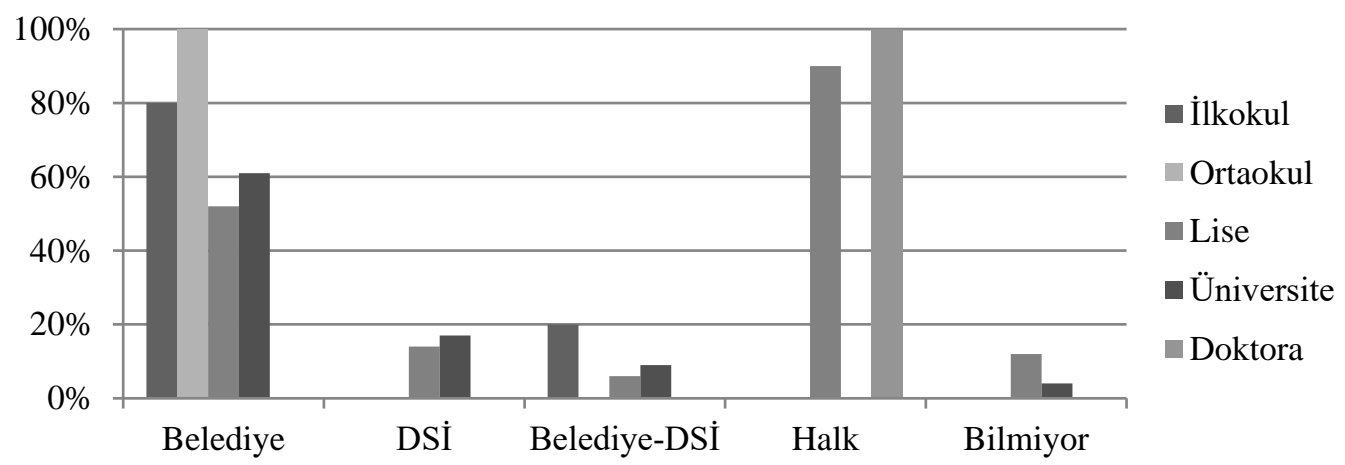

Şekil 3: 'Taşkınların önlenmesinden kim sorumludur?' sorusuna verilen yanıtların eğitim düzeyiyle ilişkisi

Yaşadıkları taşkından sonra kendilerine önlem alanlar çoğunlukla iş yeri sahibi olanlardır ve \%11 oranındadır. Önlem alanlardan bazısı iş yerlerindeki hasar görecek eşyalarını üst seviyeye taşımış, mevcut kotunda yükseltmeler yapmıştır. Dükkân sahiplerinden bazıları iş yerini sigortalatarak önlem almıştır. Önceki deneyimlerinden faydalanarak, sahip olduğu aracın park yerini değiştirip daha güvenli bölge tercih ederek maddi hasarı engelleyecek önlemler de alınmıştır. Yine yaşadığı deneyimlerden yola çıkarak ihtiyacı olabileceğini düşünerek iş yerlerine kum torbası taşıyanlar da mevcuttur. Katılımcılardan biri önlem olarak iş yerinin bir cephesini kapatıp tek cepheli hale dönüştürmüştür. Bir diğeri ise iş yerini tek cephesi olan bir yere taşımıştır. Ankete katılan diğer kesimde herhangi bir önlem alma girişime rastlanmamıştır (Durmuş 2020).

\subsection{Erken Uyarı Farkındalık Değerlendirilmesi}

Taşkınla karşı karşıya kalıp harekete geçenlerin sayısı katılımcıların yaklaşık \%35'ini oluşturmaktadır. Herhangi bir erken uyarı almayan kişiler taşkın sırasında kendi gözlem ve deneyimlerinden yola çıkarak harekete geçmesi gerektiğini anlamışlardır. Bu kişiler kendini uyarma yoluyla harekete geçmiş sayılmaktadır. 
Katılımcıların çoğu ilçe merkezinde esnaf olduğu için taşkın anında su seviyesinin yükseldiğini fark ettikleri anda iş yerlerindeki maddi kayıpları önlemeye çalıştıklarını belirtmişlerdir. Bir kısmı tezgahtaki malları kurtarırken, bir kısmı değerli evraklarını koruma altına almakla uğraştıklarını belirtmiştir. Buna ek olarak harekete geçenlerin \%20'si iş yerlerine kapıların ve pencerelerin önüne çeşitli malzemeler koyarak su seviyesinin yükselmesini engellediklerini söylemiştir. Soruyu cevaplayan katılımcılardan taşkın anında harekete geçenlerin kendi adına aldıkları önlemlerin genellikle kapı ve pencere önlerine tahta veya benzeri malzemeler yerleştirmek olduğu gözlenmiştir. Yakınını arayıp haber almak isteyenler ise katılımcıların yaklaşık \%11'ini oluşturmaktadır. Evine veya iş yerine gitmeye çalışanlar ise yaklaşık \%6 oranındadır. Harekete geçmediğini belirten katılımcılar (\%65) taşkına teslim olduğunu yapacak hiçbir şey olmadığını korku ve panikle beraber felaketin sona ermesini ve kurtarılmayı beklediklerini söylemişlerdir. Anket katılımcılarından \%4'ünün görev icabı kurtarma çalışmalarında yer aldığı görülmüştür.

'Erken uyarıyı hangi yolla almak istersiniz?' sorusuna cevap olarak \%48 oranında sokaktan hoparlör aracılığıyla sesli duyuru yanıtı alınmıştır. Katılımcıların \%19'u erken uyarıyı cep telefonlarına gelen mesaj bildirimiyle almayı tercih ettiklerini söylemiştir. Hem mesaj uyarısını hem hoparlör uyarısını tercih edenlerin oranı ise \%4'tür. Hoparlörden sesli uyarı veya cep telefonuna gelen mesaj uyarısından farklı olarak katılımcıların \%10'u televizyondan, \%9'u internet, \%6'sı ise yazılı basın aracılığıyla erken uyarı almak istediğini belirtmiş olup, \%4'ü hiçbir uyarıya güvenmediklerini belirterek uyarı almak istemediklerini söylemişlerdir. Bölge halkının iletişim tercihinin daha çok sesli uyarı üzerinde yoğunlaştığı görülmüştür. Katılımcıların çoğu yaşadıkları taşkın sonrası bölgede fazla sayıda hoparlör aracılığıyla sesli erken uyarı duyduklarını fakat bu uyarıların sonunda herhangi bir etkiye maruz kalmadıklarından dolayı yapılan sesli uyarıları artık dikkate almadıklarını belirtmişlerdir.

Katılımcılara harekete geçmeleri için gerekli olan minimum hazırlık süresi sorularak ihtiyaç olan ortalama hazırlık süresi belirlenmeye çalışılmıştır. Soruyu cevaplayan kişiler \%87 oranındadır. Kalan \%13'lük kısım ise hazırlık süresinin kendileri için önemli olmadığını belirtmişlerdir. Soruyu cevaplayan katılımcılardan 6 saatten az hazırlık süresine ihtiyaç duyanların oranı yaklaşık \%51'tür. 24 saatten fazla hazırlık süresine ihtiyaç duyanların oranı \%11, 24 saatle 6 saat arasında hazırlık süresine ihtiyaç duyanların oranı ise \%25'tir. Bu verilerden yola çıkarak ortalama hazırlık süresi 13 saat olarak hesaplanmıştır. 6 saatten az hazırlık süresine ihtiyaç duyan kişiler genellikle dükkân sahipleri olup, bu süre içinde iş yerlerindeki malları daha güvenli bir yere veya bir sığınağa taşımak için kendine yeterli olan minimum süreyi söylemişlerdir. Ev ve iş yeri mesafesi biraz daha fazla olan dükkân sahipleri ise 6 saatten daha fazla hazırlık süresine ihtiyaç duyulacağını belirtmişlerdir. 24 saatten daha fazla hazırlık süresine ihtiyacı olacağı görüşünde olan katılımcılar ise değerli eşyaları, araçları ve ailesiyle beraber bulunduğu bölgeyi terk etmek için gerekli olan minimum süreyi referans göstermişlerdir.

Kişilere bu süre zarfında hangi kayıplarını önleyebilecekleri sorulduğunda ise alınan yanıtların yarısından fazlasının maddi kayıplarla ilgili olduğu görülmüştür. İş yerlerinde bulunan malları kurtarmak ve arabalarını yüksek yerlere çıkarmak, soruya verilen yanıtlar arasındadır. Katılımcıların \%22'si sadece kendi ve yakınlarının canını kurtarmak istediğini belirtmiştir. Hem maddi hem manevi kayıplarını önleyebileceğini söyleyenlerin yüzdesi \%23 iken, hazırlık süresine ihtiyaç duymayan kişiler bu sürede herhangi bir maddi ya da manevi kaybın önlenemeyeceğini düşünmektedir. Yaş aralıklarına göre soruya verilen cevapların dağılımı Şekil 4'de gösterilmiştir.

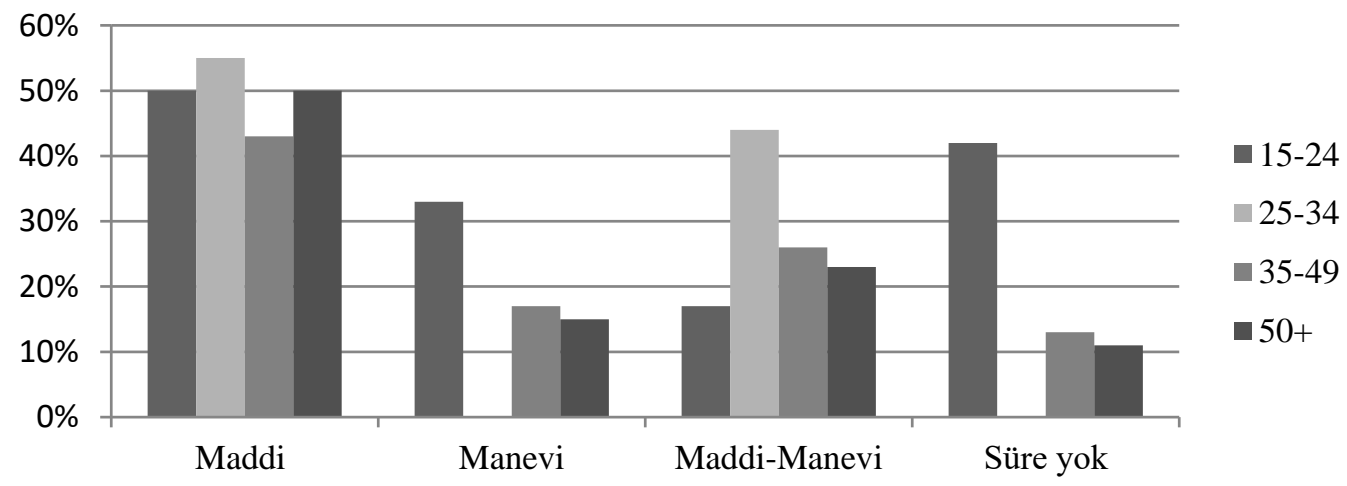

Şekil 4: 'Hazırlık süresinde önlenebilecek kayıplar nelerdir?’ sorusuna verilen cevapların yaş aralığına göre dağılımı

Olası bir taşkın anında ne yapılması gerektiğini bilenlerin yüzdesi 19 oranındadır. Katılımcıların \%81'i erken uyarı ve planlamalar hakkında bilgi sahibi olmadıklarını belirtmişlerdir. Ne yapılması gerektiğini bilen katılımcıların tümü erkektir. Ankete katılanların \%53’ü bu konuda bilgilendirme ve eğitim almak istemediklerini söylemişlerdir. Ne yapılması gerektiğini bilenlerin \%68'i yine de eğitim almak istediğini belirtmiştir. Erken uyarı ya da taşkın anında ne yapılması gerektiğini bilmeyen katılımcılardan eğitim almak isteyenlerin oranı yaklaşık \%41'dir. Bu kişilerin \%57'si risk altında olduklarını düşündüklerini belirtmişlerdir. Yine herhangi bir uyarı ya da taşkın esnasında ne yapılması gerektiğini bilmeyen \%81'lik kısımda kendini risk altında görenlerin oranı \%63 olup, bu kişilerin \%45'i eğitim almak istememektedir (Durmuş 2020). 


\subsection{Olay Ağacı}

Katılımcıların \%18'i taşkından önce erken uyarı aldıklarını ifade ederken \%82'si herhangi bir uyarı almadıklarını belirtmişlerdir. Erken uyarı aldığını söyleyen kişiler bu uyarıları resmi yolla aldıklarını söylemişlerdir. Bu kişilerin \%94'ü uyarıya güvendiğini söylese de önlem almak için harekete geçmemişlerdir. Uyarıya güvenmediğini söyleyip önlem amaçlı harekete geçmeyen kişilerin oranı ise \%6'dır. Hiçbir şekilde erken uyarı almadığını söyleyen kişilerin çoğu, felakete maruz kaldığını anladığı anda harekete geçmiştir. Sadece erken uyarı aldığını belirten \%18 oranındaki katılımcılara yöneltilen sorulara verilen $(\mathrm{E} / \mathrm{H})$ oranları Tablo 12'de sunulmuştur.

Tablo 12: Erken uyarı alanların E/H sorularına verdiği yanıt oranları

\begin{tabular}{lcc}
\hline Sorular & Evet (\%) & Hayır (\%) \\
\hline 13.Risk altında olduğunuzu anladınız mı? & 22 & 78 \\
14.Erken uyarıya güvendiniz mi? & 94 & 6 \\
15.Uyarıdan sonra ne yapacağınızı biliyor muydunuz? & 44 & 56 \\
16.Önlem için harekete geçtiniz mi? & 0 & 100 \\
\hline
\end{tabular}

Bölge halkının bilgi düzeyini, bilinçliliğini ve farkındalığını ölçmek adına bu soruların birbiriyle olan ilişkisi aşağıdaki gibi bir olay ağacında incelenmiştir (Şekil 5). Olay ağacı verilerine göre risk altında olduğunu düşünen kişiler $\% 60$ oranındadır ve bunların \%51'i ise taşkın anında ne yapılacağını bilmemektedir. Kendini risk altında hissetmesi ve olası bir taşkın anında ne yapılmasını gerektiğini bilmemesine rağmen erken uyarı ve planlamalar konusunda bilgilendirme veya eğitim almak istemeyenler \%31 oranındadır ve bu oran toplumun taşkınlarla baş etme konusunda bilinçli olmadığını göstermektedir.

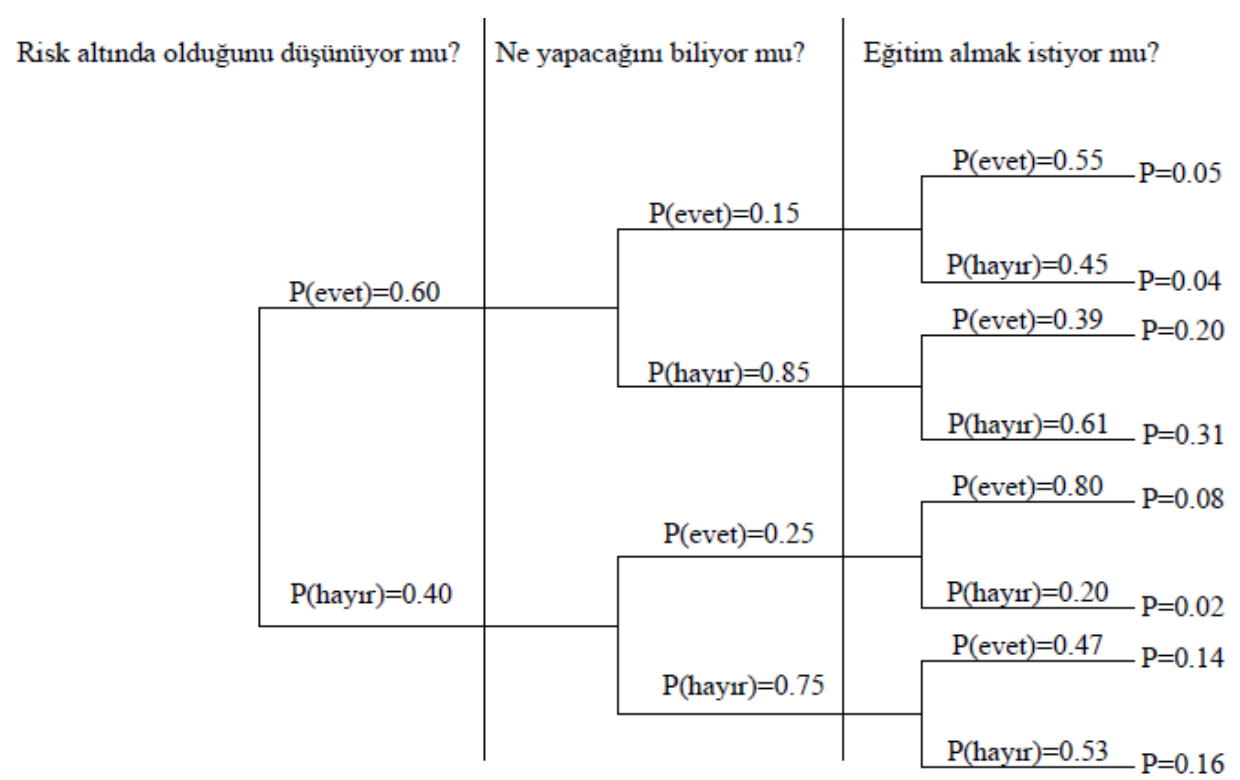

Şekil 5: Olay ağacı farkındalık analizi

Yapılan ankette taşkından önce erken uyarı alanların oranı \%18'dir. Bu kişilerin hiçbiri olaydan önce önlem olarak harekete geçmemiştir. Olay ağacında da görüldüğü üzere uyarıya güvenilmesi harekete geçme eğilimini tetiklememiştir (Şekil 6). Kişilerin uyarıya güvense bile herhangi bir erken uyarı anında yapılacaklar hakkında yeterli bilgi ve tecrübe sahibi olmadıkları için harekete geçme durumunda doğru hamleler yapma olasılığının düşük olduğu belirlenmiştir. Ayrıca eğitim düzeyi arttıkça veya taşkın anında ne yapacağını bilen yani bilinç düzeyi arttıkça eğitim alma isteğinin de arttığ1 görülmektedir (Durmuş 2020). 


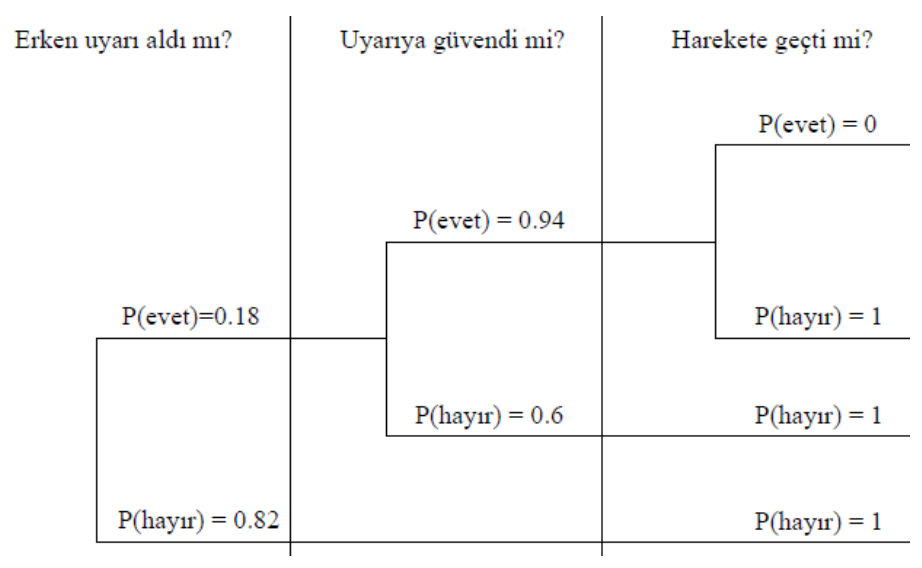

Şekil 6: Olay ağacı erken uyarı analizi

\section{Sonuç ve Öneriler}

Bu çalı̧̧mada 21 Eylül 2016 tarihinde Trabzon’un Beşikdüzü İlçesinde meydana gelen ve büyük miktarda can ve mal kaybıyla sonuçlanan taşkın, hidrolojik ve sosyal yönden incelenmiştir. Bu amaçla, ilk olarak yaşanan taşkının kaç yıl tekerrür süreli taşkın debisine karşılık geldiğini belirlemek için bölgesel taşkın frekans analizi ile çeşitli tekerrür süreli taşkın debileri hesaplanmıştır. L-momentlerle yapılan taşkın frekans analizine göre Beşikdüzü’nde meydana gelen bu şiddette bir yağışın görülme ihtimalinin, tüm standart zamanlarda 100 yllın civarında olduğu gözlemlenmiştir. İkinci olarak; bölge halkının bilgi düzeyini, bilinçliliğini ve farkındalığını ölçmek, aynı zamanda erken uyarı sistemindeki ihtiyaçları belirlemek adına taşkın olayını yaşayan bölge halkıyla anket yapılmışırı ve soruların birbiriyle olan ilişkisi bir olay ağacında incelenmiştir. Taşkın farkındalık kapsamında, kişilerin farkındalıklarının düşük olduğu, taşkınların önlenemeyeceği düşüncesinin daha yaygın olduğu ve taşkınları önlemede sorumlu kuruluşlar hakkında bilgi düzeylerinin yeterli olmadığı sonucuna varılmıştır. Kendini risk altında hissetmeyen ve olası bir taşkın anında ne yapılmasını gerektiğini bilmeyen kişilerde bile erken uyarı ve planlamalar konusunda bilgilendirme veya eğitim almak istemeyenler \%31 oranındadır ve bu oran toplumun taşkınlarla baş etme konusunda bilinçli ve gönüllü olmadığını göstermektedir. Kişilerin uyarıya güvense bile herhangi bir erken uyarı anında yapılacaklar hakkında yeterli bilgi ve tecrübe sahibi olmadıkları için harekete geçme durumunda doğru hamleler yapma olasılı̆ıının düşük olduğu belirlenmiş̧ir. Bu makale çalışmasından elde edilen sonuçlara dayanarak yapılan öneriler şu şekilde özetlenmiştir:

- Taşkın farkındalığını ve risk bilincini ölçmek adına yapılmış olan sosyal çalışma sonucunda havza geneli ve riskli alanlar için taşkın tehlikesinin ve taşkından zarar görebilirliğin azaltılması, taşkına karşı direncin arttırılması ve taşkın tehlikesiyle beraber taşkın riski hakkında bilginin geliştirilmesi gerektiği belirlenmiştir. Taşkın tahmininde erken uyarının önemi ve anlaşılma eğilimine ait temel durumun tanımlanması için sadece kentsel alanların taşkın riskini tahmin etmek amacıyla değil, aynı zamanda her yapısal olmayan önlemin potansiyel sonuçları nasıl etkileyeceğini analiz etmek için bir temel oluşturmak amaciyla mevcut risk bilincinin analiz edilmesi gerekmektedir.

- Kamuoyu araştırmasının başarısını ve sonuçların daha fazla kullanılmasını garanti altına almak için yerel yönetimlerin de dahil olması gereken toplum temelli önlemler alınması gerekmekte ve bu önlemlerin vatandaş girişimleri, sivil toplum kuruluşları veya bu alanda çalışan diğer kamu kurum ve kuruluşlarla entegre edilmesi gerekmektedir.

- Toplumda güven duygusunu zedelememek adına yapılan uyarıların geçerliliği kontrol edilmeli, alarm seviyesi düşük, yüksek veya çok yüksek olaylar için farklı uyarı yolları tercih edilmelidir.

- Taşkın debisi tahminlerinde kullanılan akarsu gözlem istasyonlarının ölçüm sırasında yatak oyulmaları ve çeşitli malzeme birikintileri yüzünden doğru sonuç verememesi nedeniyle, bunun yerine GSM / GPRS modem aracilı̆̆ ile uzaktan veri okuyabilen, yüzey su seviyesi ölçümleri için yüksek doğrulukta temassız ölçüm sistemi içeren radar sensörlü limnigraflar kullanılmalıdır.

- Ölçüm cihazından gelen mikrodalga sinyallerinden malzeme yüzeyine olan uzaklığın saptanması ve bu sayede seviye hesaplanmasıyla seviyeye bağlı debi ve hacim ölçümü yapılıp öngörülen tehlike karşısında erken uyarılar yapilmalidır.

- Uyarılar halk ve diğer kamu kuruluşlarına iletilmeli böylece toplum temelli erken uyarı sistemi geliştirilmelidir.

- Sistemin doğruluğu, güvenilirliği, zamanında ve geçerli uyarı yayma potansiyeli incelenmeli, uyarılar ve uyarı sonrası yapılması gerekenlere karşı halk, sivil toplum örgütleri ve diğer kamu kuruluşları bilgilendirilmelidir.

- İnsanların taşkın farkındalık bilincinin ve erken uyarı sistemleri hakkında bilgilerinin arttırılmasına yönelik çalışmalar yapılmalıdır. Bu kapsamda, Trabzon İli’nde yapılan Taşkın Müzesi, halkın taşkın zararlarına karşı hem önceden hem de taşkın anında alınabilecek önlemler hakkında bilgi sahibi olmalarını sağlayacaktır. 


\section{Kaynaklar}

Akçalı E., (2018), Taşkın ve rusubat kontrolünde yenilikçi uygulamalar, 2. Uluslararası Doğal Afetler ve Afet Yönetimi Sempozyumu, 4-6 Mayıs, Sakarya, ss.31-40.

Alfieri L., Salamon P., Pappenberger F., Wetterhall F., Thielen J., (2012), Operational early warning systems for water-related hazards in Europe, Environmental Science and Policy, 21, 35-49.

Anılan T., (2014), Doğu Karadeniz Havzası 'nın L-momentlere dayalı taşkın frekans analizinde yapay zeka yöntemlerinin uygulanması, Doktora Tezi, Karadeniz Teknik Üniversitesi, Fen Bilimleri Enstitüsü, Trabzon.

Anılan T., Yüksek Ö., (2017), Perception of flood risk and mitigation: survey results from the Eastern Black Sea Basin, Turkey, Natural Hazards Review, 18(2), 05016006, doi: 10.1061/(ASCE)NH.1527-6996.0000232.

Anilan T., Uzlu E., Kankal M., Yüksek Ö., (2018), The estimation of flood quantiles in ungauged sites using teaching- learning based optimization and artificial bee colony algorithms, Scientia Iranica, 25(2), 632-645.

Doswell C.A., Brooks H.E., Maddox R.A., (1996), Flash flood forecasting: an ingredients based methodology, Weather and Forecasting, 11(4), 560-581.

DSİ, (2016), Beşikdüzü Taşkın Raporu, DSİ 22. Bölge Müdürlüğü, Trabzon.

Durmuş H., (2020), Taşkın farkındalık ve erken uyarı sistemleri değerlendirmesi: Trabzon Beşikdüzü örneği, Yüksek Lisans Tezi, Karadeniz Teknik Üniversitesi, Fen Bilimleri Enstitüsü, Trabzon.

Gautam D.K., Phaiju A.G., (2013), Community based approach to flood early warning in West Rapti River Basin of Nepal, IDRiM Journal, 3(1), 155-169.

Gebeyehu A., (1989), Regional flood frequency analysis, The Royal Institute of Technology, Stockholm, Sweden, Bulletin No. TRIVAVBI-148, 169ss.

Hosking J.R.M., (1986), The theory of probability weighted moments. Research Rep. RC 12210, IBM Research Division, Yorktown Heights, New York, USA. 160ss.

Hosking J.R.M., (1990), L moments: Analysis and estimation of distributions using linear combinations of order statistics, Journal of the Royal Statistical Society Series B, 52, 105-24.

Hosking J.R.M., Wallis J.R., (1988), The effect of intersite dependence on regional flood frequency analysis, Water Resources Research, 24, 4, 588-600.

Hosking J.R. M., Wallis J.R., (1993), Some statistics useful in regional frequency analysis, Water Resources Research, 29, 2, $271-281$.

Hosking J.R.M., Wallis J.R., (1997), Regional frequency analysis: an approach based on l-moments, IBM Research Division, Yorktown Heights, New York, USA. 224ss.

Karaman Z.T., (2018), Afetlerde erken uyarı ve toplumsal farkındalı yaratmada etkili kamu politikaları, Bitlis Eren Üniversitesi, Sosyal Bilimler Enstitüsü Dergisi, 7(2), 493-517.

Kreibich H., Thieken A.H., Petrow T., Muller M., Merz B., (2005), Flood loss reduction of private households due to building precautionary measures-lessons learned from the Elbe Flood in August 2002. Natural Hazards and Earth Systems Sciences, 5(1), $117-126$.

Lindell M.K., Perry R.W., (2000), Household adjustment to earthquake hazard, Environmental Behavior, 32(4), 461-501.

Molinari D. ve Handmer J., (2011), A behavioural model for quantifying flood warning efectiveness, Journal of Flood Risk Management, 4(1), 23-32.

Norris F.H., Smith T., Kaniasty K., (1999), Revisiting the experiencebehavior hypothesis: the effects of hurricane hugo on hazard preparedness and other self-protective acts, Basic Applied Social Psychology, 21(1), 37-47.

Parker D.J., Priest S.J., Tapsell S.M., (2009), Understanding and enhancing the public's behavioural response to flood warning information, Meteorological Applications: A Journal of Forecasting, Practical Applications, Training Techniques and Modelling, 16(1), 103-114.

Sarıcan Y., (2013), Taşkın tehlikesinin belirlenmesi amacı ile otomatik yağış miktarı ölçüm sisteminin gelişstirilmesi, Yüksek Lisans Tezi, Hacettepe Üniversitesi, Fen Bilimleri Enstitüsü, Ankara.

Seçkin N., Cobaner M., Yurtal R., Haktanir T., (2013), Comparison of artificial neural network methods with l-moments for estimating flood flow at ungauged sites: the case of East Mediterranean River Basin, Turkey, Water Resources Management, 27, $2103-2124$.

Sorensen J.H., (2000), Hazard warning systems: review of 20 years of progress, Natural Hazards Review, 1(2), 119-125.

SYGM, (2017), Taşkın Yönetimi, T.C. Orman ve Su İşleri Bakanlığı, Su Yönetimi Genel Müdürlüğü, Ankara, 248ss.

Şorman Ü., Okur A., (2000), L-momentler tekniği kullanılarak noktasal ve bölgesel frekans analizinin uygulanması, İMO Teknik Dergi, 2199-2216.

Thiemig V., de Roo A., Gadain H., (2011), Current status on flood forecasting and early warning in Africa, International Journal of River Basin Management, 9(1), 63-78.

Uşkay S., Aksu S., (2002), Ülkemizde taşkınlar, nedenleri, zararları ve alınması gereken önlemler, Türkiye Mühendislik Haberleri, 47(4-6), 133-136.

Vogel R.M., Fennessey N.M., (1993), L moment diagrams should replace product moment diagrams, Water Resources Research, 29,6, 1745-1752.

Yüksek Ö., Serencam U., Üçüncü O., Anılan T., (2013), Afet ve taşkın yönetimi ve Değirmendere örneği, Taşkın ve Heyelan Sempozyumu, 24-26 Ekim, Trabzon, ss.33-44.

Zaleskiewicz T., Piskorz Z., Borkowska A., (2002), Fear or money? Decisions on insuring oneself against flood, Risk Decision Policy, 7(3), 221-233. 